\title{
Consideraciones clínicas sobre la ciclosporosis
}

\author{
Jorge Alberto Castañón-González y Víctor Zavala-González
}

Secretaría de Salud, Hospital Juárez de México, Ciudad de México, México

La ciclosporosis en una enfermedad que afecta el intestino delgado causada por el parásito Cyclospora cayetanensis. Se adquiere al ingerir agua o alimentos contaminados con oocitos del parásito, no se transmite de persona a persona sino que la transmisión es fecal-oral; auque Cyclospora cayetanensis completa su ciclo de vida en el humano, oocistos expulsados en las heces fecales de las personas infectadas deben madurar y pasar a espórulas fuera del huésped, lo que tarda una a dos semanas en un medio ambiente propicio con temperaturas entre 23 y $27{ }^{\circ} \mathrm{C}$, en zonas tropicales o subtropicales.

Desde el punto de vista epidemiológico, la ciclosporosis se presenta con brotes en verano y otoño. Destaca que las espórulas no se eliminan con el uso de los desinfectantes comúnmente utilizados en la industria de alimentos y en el tratamiento del agua. Es sensible a tratamiento médico con trimetoprim/ sulfametoxazol $160 / 800 \mathrm{mg}$ y no responde a los antiparasitarios habituales. En zonas endémicas la infección es asintomática. ${ }^{1}$

La ingestión de Cyclospora cayetanensis por adultos inmunocompetentes en áreas no endémicas siempre será sintomática, caracterizada por anorexia, náusea, flatulencia, fatiga, cólicos abdominales, periodos prolongados de diarrea acuosa intermitente que fluctúa entre cinco y 15 evacuaciones al día, que resulta en pérdida ponderal. El periodo de incubación es de una semana en promedio (dos a 14 días). Si el paciente no recibe tratamiento, la enfermedad evoluciona con remisiones y recaídas. Se han reportado complicaciones como malabsorción intestinal, colecistitis y artritis reactiva. Para efectuar el diagnóstico hay que solicitar en forma específica la visualización de los oocitos de Cyclospora por medio de tinción de
Zieh-Neelsen modificada en frío, por técnicas moleculares o por un panel de patógenos gastrointestinales por reacción en cadena de la polimerasa (PCR). Se pueden requerir varias muestras, ya que los 00cistos de Cyclospora pueden ser expulsados en las heces en forma intermitente y en pequeñas cantidades, aun cuando exista diarrea profusa.

Si bien se han reportado pocos casos en México, ${ }^{2}$ se ha confirmado un incremento en turistas..$^{2-4} \mathrm{El}$ propósito de este comunicado en alertar a la comunidad médica, en particular a la de primer contacto, que existe una alerta epidemiológica en Estados Unidos por dicho incremento, así como describir cinco pacientes previamente sanos con diarrea prolongada intermitente y pérdida ponderal, referidos a los autores. Los cinco habían sido evaluados previamente con coproparasitoscópicos seriados, estudios coprológicos, coprocultivos y dos de ellos con colonoscopia (Tabla 1).

De los cinco pacientes, en tres (pacientes 3,4 y 5 ) se efectuó el panel para patógenos gastrointestinal Film Array ${ }^{\circledR}$; solo en dos (casos 4 y 5 ) se confirmó ciclosporosis por PCR, quienes presentaron resolución de la sintomatología al recibir trimetoprim/sulfametoxazol. En los otros tres casos, como el contexto clínico era semejante al de los dos casos confirmados, y a pesar de que uno tenía reporte de panel gastrointestinal por PCR sin detección de patógenos gastrointestinales (probablemente debido a que el parásito se expulsa por las heces fecales en forma intermitente), decidimos tratar con trimetoprim/sulfametoxazol por 10 días, con lo que se obtuvo buena respuesta. Durante el seguimiento durante ocho meses, todos los pacientes recuperaron peso, sin síntomas gastrointestinales.
Fecha de recepción: 15-05-2019

Fecha de aceptación: 16-05-2019

DOI: 10.24875/GMM.19005284
Gac Med Mex. 2019;155:328-329

Disponible en PubMed www.gacetamedicademexico.com 
Tabla 1. Descripción de casos clínicos con cliclosporosis

\begin{tabular}{|c|c|c|c|c|c|c|}
\hline Casos & $\begin{array}{l}\text { Sexo/ } \\
\text { edad }\end{array}$ & Evolución & Antecedentes & Cuadro clínico & Laboratorio & Seguimiento \\
\hline 1 & $\begin{array}{l}\text { Mujer } \\
\text { sueca de } \\
26 \text { años }\end{array}$ & 5 meses & $\begin{array}{l}\text { Estancia previa } \\
\text { en Nepal y } \\
\text { Tailandia, donde } \\
\text { se iniciaron los } \\
\text { síntomas }\end{array}$ & $\begin{array}{l}\text { Diarrea acuosa } \\
\text { intermitente, promedio de } \\
6 \text { evacuaciones al día, } \\
\text { pérdida ponderal de } 8 \\
\text { kg, dolor abdominal en } \\
\text { mesogastrio, tipo cólico, } \\
\text { de leve a moderada } \\
\text { intensidad, anorexia, } \\
\text { febrícula, náuseas, } \\
\text { flatulencias }\end{array}$ & $\begin{array}{l}\text { Evaluada en Suecia con } \\
\text { coproparasitoscópico } \\
\text { seriado y colonoscopia. } \\
\text { Recibió metronidazol }\end{array}$ & $\begin{array}{l}\text { Resolución de los síntomas } \\
\text { después de } 10 \text { días de } \\
\text { tratamiento con trimetoprim/ } \\
\text { sulfametoxazol. } \\
\text { Recuperó } 3 \mathrm{~kg} \text { a los dos } \\
\text { meses }\end{array}$ \\
\hline 2 & $\begin{array}{l}\text { Mujer de } \\
76 \text { años }\end{array}$ & 5 meses & $\begin{array}{l}\text { Ingesta de } \\
\text { cocteles de } \\
\text { mariscos en } \\
\text { Acapulco, } \\
\text { Guerrero, } \\
\text { México }\end{array}$ & $\begin{array}{l}\text { Diarrea intermitente, } \\
\text { hasta } 8 \text { evacuaciones al } \\
\text { día, anorexia, flatulencia, } \\
\text { incontinencia fecal, dolor } \\
\text { abdominal generalizado, } \\
\text { de baja intensidad e } \\
\text { intermitente, pérdida } \\
\text { ponderal de } 8 \text { kg }\end{array}$ & $\begin{array}{l}\text { Coproparasitoscópico } \\
\text { seriado, tratamiento } \\
\text { previo con rifaximina y } \\
\text { metronidazol }\end{array}$ & $\begin{array}{l}\text { Resolución de los síntomas } \\
\text { después de } 10 \text { días con } \\
\text { trimetoprim/sulfametoxazol. Al } \\
\text { mes recuperó } 2 \mathrm{~kg}\end{array}$ \\
\hline 3 & $\begin{array}{l}\text { Hombre } \\
\text { de } \\
43 \text { años }\end{array}$ & 3 meses & $\begin{array}{l}\text { Ingesta de } \\
\text { camarones en } \\
\text { la Ciudad de } \\
\text { México }\end{array}$ & $\begin{array}{l}\text { Diarrea, } 6 \text { a } 8 \text { evacuaciones } \\
\text { al día, anorexia, pérdida } \\
\text { ponderal de } 4 \mathrm{~kg} \text {, dolor } \\
\text { abdominal posprandial } \\
\text { intermitente de baja } \\
\text { intensidad }\end{array}$ & $\begin{array}{l}\text { Coproparasitoscópico } \\
\text { seriado, colonoscopia, } \\
\text { panel para patógenos } \\
\text { gastrointestinales } \\
\text { por PCR. No se } \\
\text { identificó Cyclospora } \\
\text { cayetanensis }\end{array}$ & $\begin{array}{l}\text { Resolución de los síntomas } \\
\text { después de } 10 \text { días de } \\
\text { tratamiento con trimetoprim/ } \\
\text { sulfametoxazol. Recuperó su } \\
\text { peso habitual }\end{array}$ \\
\hline 4 & $\begin{array}{l}\text { Hombre } \\
\text { de } \\
36 \text { años }\end{array}$ & 3 meses & $\begin{array}{l}\text { Viaje previo al } \\
\text { mar Caribe en } \\
\text { México }\end{array}$ & $\begin{array}{l}\text { Diarrea intermitente, } \\
6 \text { evacuaciones al día } \\
\text { en promedio, dolor } \\
\text { intermitente en hipogastrio, } \\
\text { pérdida ponderal de } 4 \text { kg }\end{array}$ & $\begin{array}{l}\text { Coproparasitoscópico } \\
\text { seriado, panel } \\
\text { gastrointestinal por } \\
\text { PCR. Se identificó } \\
\text { patógeno. Tratado con } \\
\text { albendazol y rifaximina }\end{array}$ & $\begin{array}{l}\text { Asintomático después de } \\
\text { tratamiento con trimetoprim/ } \\
\text { sulfametoxazol. Recuperó su } \\
\text { peso habitual }\end{array}$ \\
\hline 5 & $\begin{array}{l}\text { Hombre } \\
\text { de } \\
69 \text { años }\end{array}$ & 6 meses & $\begin{array}{l}\text { Ingesta de } \\
\text { cocteles de } \\
\text { mariscos en } \\
\text { Zihuatanejo, } \\
\text { Guerrero, } \\
\text { México }\end{array}$ & $\begin{array}{l}\text { Diarrea intermitente, } 5 \text { a } \\
6 \text { evacuaciones al día, } \\
\text { pérdida ponderal de } 4 \\
\text { kg, flatulencia, molestias } \\
\text { abdominales inespecíficas }\end{array}$ & $\begin{array}{l}\text { Coproparasitoscópico } \\
\text { seriado, colonoscopia } \\
\text { con biopsias, panel } \\
\text { gastrointestinal por PCR. } \\
\text { Se identificó Cyclospora } \\
\text { cayetanensis }\end{array}$ & $\begin{array}{l}\text { Asintomático después de } \\
\text { tratamiento con trimetoprim/ } \\
\text { sulfametoxazol. Recuperó su } \\
\text { peso habitual }\end{array}$ \\
\hline
\end{tabular}

El antecedente de viaje reciente y el contexto clínico similar al descrito en un paciente con diarrea con remisiones y recaídas por semanas o meses, apoyan el diagnóstico y justifican un tratamiento con trimetoprim/ sulfametoxazol. El diagnóstico diferencial deberá siempre incluir los síndromes de colon irritable y malabsorción intestinal, enfermedad inflamatoria intestinal y cáncer de colon (adenoma velloso), entre otros.

\section{Bibliografía}

1. Ortega YR, Sánchez R. Update in Cyclospora cayetanensis. A food-borne and waterborne parasite. Clin Microbiol Rev. 2010;23:2018-234.

2. Ponce-Macotela M, Cob-Soca C, Martínez-Gordillo MN. Cyclospora in two Mexican children. Rev Invest Clin 1996;48:461-463.

3. Centers for Disease Control and Prevention. Increase in reported cases of Cyclospora cayetanensis infection, United States, Summer 2017, CDCHAN 00405, Health Alert Network, August 7, 2017.

4. Casillas SM, Bennett C, Straily A. Notes from the field: multiple cyclosporiasis outbreaks-United States, 2018. MMWR Morb Mortal Wkly Rep. 2018;67(39):1101-1102. 